\title{
E-Learning Model to Support Industrial Based Adaptive Learning for Student Vocational High School
}

\author{
Rian Andrian ${ }^{1}$, Ahmad Fauzi ${ }^{2}$ \\ ${ }^{1,2}$ Education, System and Information Technology Department \\ Universitas Pendidikan Indonesia, Purwakarta, Indonesia \\ 1rianandrian@upi.edu, 2ahmad.fauzi@upi.edu
}

\begin{abstract}
Vocational High Schools have an important role in improving the quality of human resources to meet industrial needs. However, the current education system in Vocational Schools especially in Purwakarta, Subang, Karawang, Bekasi (PURWASUKASI) still has disadvantages compared to other countries. The government through the ministry of industry has started vocational education for Vocational Schools in Indonesia. Vocational education conducted to support the creation of qualified human resources that can meet the industrial needs related to labor. The implementation of information technology in the field of education is one of the ways to improve the quality of education, including education in vocational schools. Elearning implementation aims to improve the quality of education. E-learning is often used in the application of adaptive learning in the field of education. In this study, an e-learning system model has been created that has been developed to support industrial based adaptive learning for Vocational High Schools in PURWASUKASI. The system that has been developed has been tested from the functional side of the system and shows that the developed e-learning system is ready to use.
\end{abstract}

Keywords- e-learning, adaptive learning, Vocational High Schools, PURWASUKASI

\section{INTRODUCTION}

Vocational High School Education (SMK) has an important role in improving the quality of human resources to meet industrial needs. However, the current education system in Vocational Schools still cannot compete compared to other countries. The government through the ministry of industry has started vocational education for Vocational Schools in Indonesia. Vocational education is conducted so that the education system can meet the industrial needs related to qualified human resources[1]. Improving the quality of education in Vocational Schools needs to be done to help prepare reliable candidates for industry needs. Badan Pusat Statistik (BPS) in collaboration with the Asosiasi Penyelenggara Jasa Internet Indonesia (APJII) in its survey noted that the growth in the use of internet technology in Indonesia by the end of 2013 had reached 71.19 million people, dominated by the younger generation[2]. The results of a survey conducted by BPS and APJII show that technology is currently dominantly used in Indonesia, especially students in the high school level.

The implementation of information technology in the field of education is one of the ways to improve the quality of education, including education in vocational schools. This is driven by the Peraturan Presiden Nomor 17, 2010[3], regarding the implementation of national education information systems based on information and communication technology (ICT), and also recommendations for implementing ICT-based learning by the government in using the 2013 curriculum (K-13) for education in Indonesia. In addition, vocational education, in particular, is expected to always and constantly with the technology to improve the quality of education, especially for the education field in the learning process.

E-learning is the technology that compatible to implement in education field. The use of e-learning aims to improve the quality of education. E-learning in its implementation is often used in the application of adaptive learning in the field of education today. Adaptive learning is an educational method that uses information technology to regulate interactions with students and provide resources with learning activities that meet the needs of students. The use of e-learning will impacted for producing qualified human resources. But in reality, the use of e-learning in Vocational Schools, especially in Purwakarta, Subang, Karawang (PURWASUKASI) is not yet maximal implemented. Based on the survey results, there are several obstacles faced in the use of e-learning, namely:

1. A lot of Vocational High School still do not have e-learning;

2. E-learning has not been fully utilized by the teacher;

3. The teacher is still have a lot of task, so the time to conducting e-learning is very lacking.

This study will develop an e-learning model to solve these problems. The proposed e-learning model is expected to support industrial-based adaptive learning for vocational students. 


\section{METHOD}

\section{A. VOCATIONAL HIGH SCHOOL (SMK)}

Vocational Schools have important role in supporting the fulfillment of reliable human resources for industrial needs. However, the current education system in Vocational Schools still cannot compete compared to other countries. The government through the ministry of industry has now started vocational education for Vocational Schools in Indonesia. Vocational education is conducted so that the education system can meet the industrial needs related to qualified human resources[1].

\section{B. INFORMATION TECHNOLOGY}

Information Technology (IT) is a general term for any technology that helps humans to make, change, store, communicate and/or disseminate information. The development of information technology is increasingly rapid in the globalization era and its influence for education field[4].

The role of information technology in the field of education are:

1. As an educational infrastructure

2. As a tool and learning facilities

3. As support for education management

\section{E-LEARNING}

E-learning is one of the implementations of information technology in the field of education. Elearning is also known as electronic learning[5]. Masrom mentions e-learning is all forms of education facilitated by the internet and technology. It includes the use of the World Wide Web (www) to support instruction to deliver the contents of the lesson[6]. The ILR of Bristol University also defines e-learning as the use of electronic technology to send, support, and improve teaching, learning, and assessments[7].

\section{ADAPTIVE LEARNING}

Adaptive learning is an educational method that uses information technology to regulate interactions with students and provide resources with learning activities that meet the needs of students. Adaptive learning is driven by the awareness that the learning process cannot be achieved on a large scale using traditional approaches. Adaptive learning systems seek to transform learners from passive information receptors into collaborators in the educational process[8].

\section{E. MOODLE}

Moodle (Modular Object-Oriented Dynamic Learning Environment) is an open source e-learning platform. Moodle can be downloaded for free, used and modified by everyone with the General Public License (GNU)[9]. Moodle supports student center learning and distance learning. Through the concept of learning, students can easily access material and attend learning anywhere without any distance and time constraints. Besides that, the teacher can provide material not limited by distance, space, and time. Teachers can upload material in the form of words, presentations, audio, videos, links from other webs, etc.

\section{F. DEVELOPMENT METHOD}

In this study, Development Life Cycle (SDLC) used as a development approach. SDLC is a workflow used in the design, development, and system testing process to produce quality products[10]. In this study, The SDLC model that used is a throwaway prototyping model. The system development process uses a throwaway prototyping model consisting of planning, analysis (analysis, design, implementation), design and implementation.

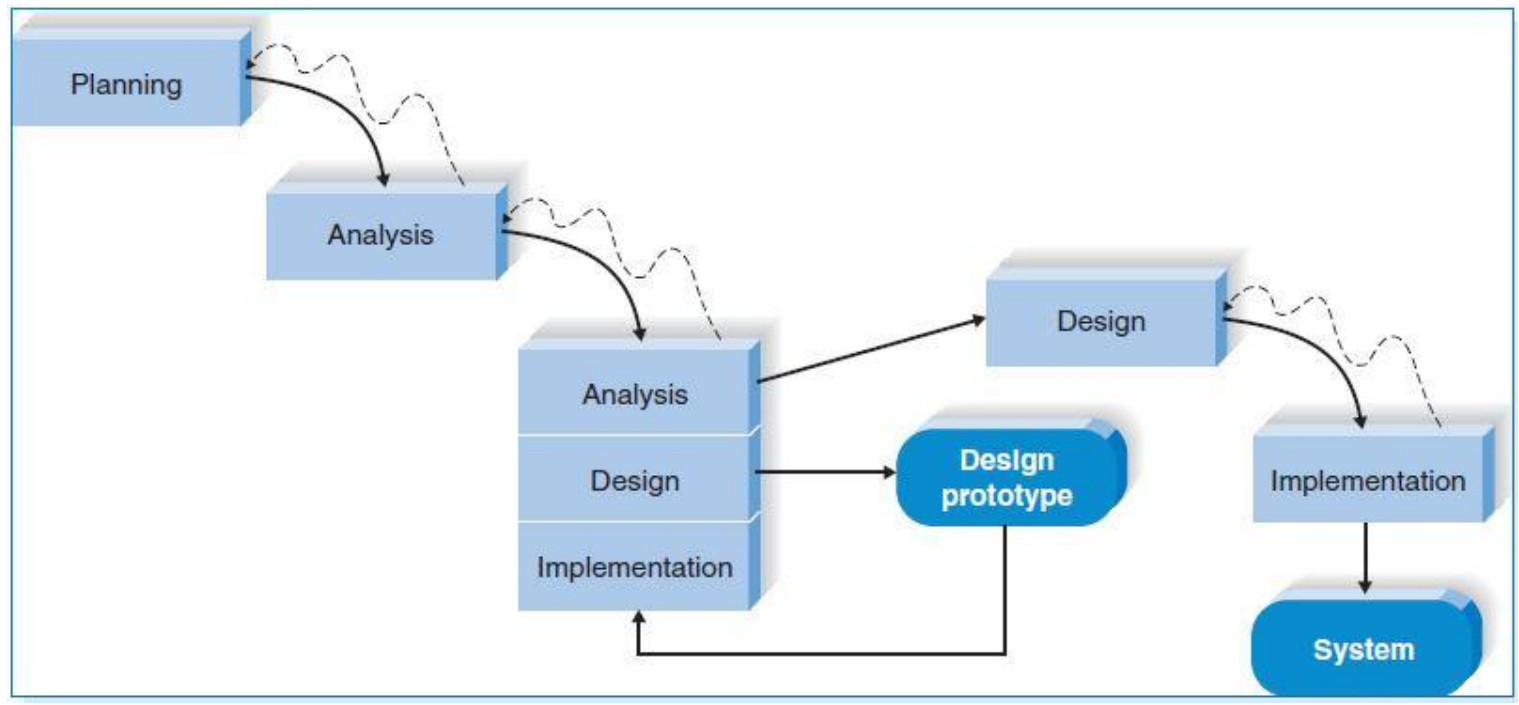

Figure 1. Throwaway Prototyping Method 


\section{RESULT AND DISCUSSION}

\section{A. REQUIREMENTS ANALYSIS}

This study aims to develop an e-learning model that supports industrial-based adaptive learning for vocational students. There are several actors involved in the use of elearning as one of the supporting tools of the teaching and learning process including Administrators, Teachers, Students and also industries as external entities that must be considered by the Teacher in preparing teaching materials for the teaching and learning process.

From each actor involved, functional requirements are defined. Functional requirements in developing a system are the functions that must be fulfilled by the developed system. The following is a list of recorded functional requirements:

Table 1. Functional Requirement

\begin{tabular}{cl}
\hline ID & \multicolumn{1}{c}{ Requirement } \\
\hline FR01 & $\begin{array}{l}\text { A system should facilitate administrator to add } \\
\text { users to the system }\end{array}$ \\
\hline FR02 & $\begin{array}{l}\text { A system should facilitate administrator to } \\
\text { define users status }\end{array}$ \\
\hline FR03 & $\begin{array}{l}\text { A system should facilitate administrator to } \\
\text { manage users role }\end{array}$ \\
\hline FR04 & $\begin{array}{l}\text { A system should facilitate administrator to } \\
\text { create course categories }\end{array}$ \\
\hline
\end{tabular}

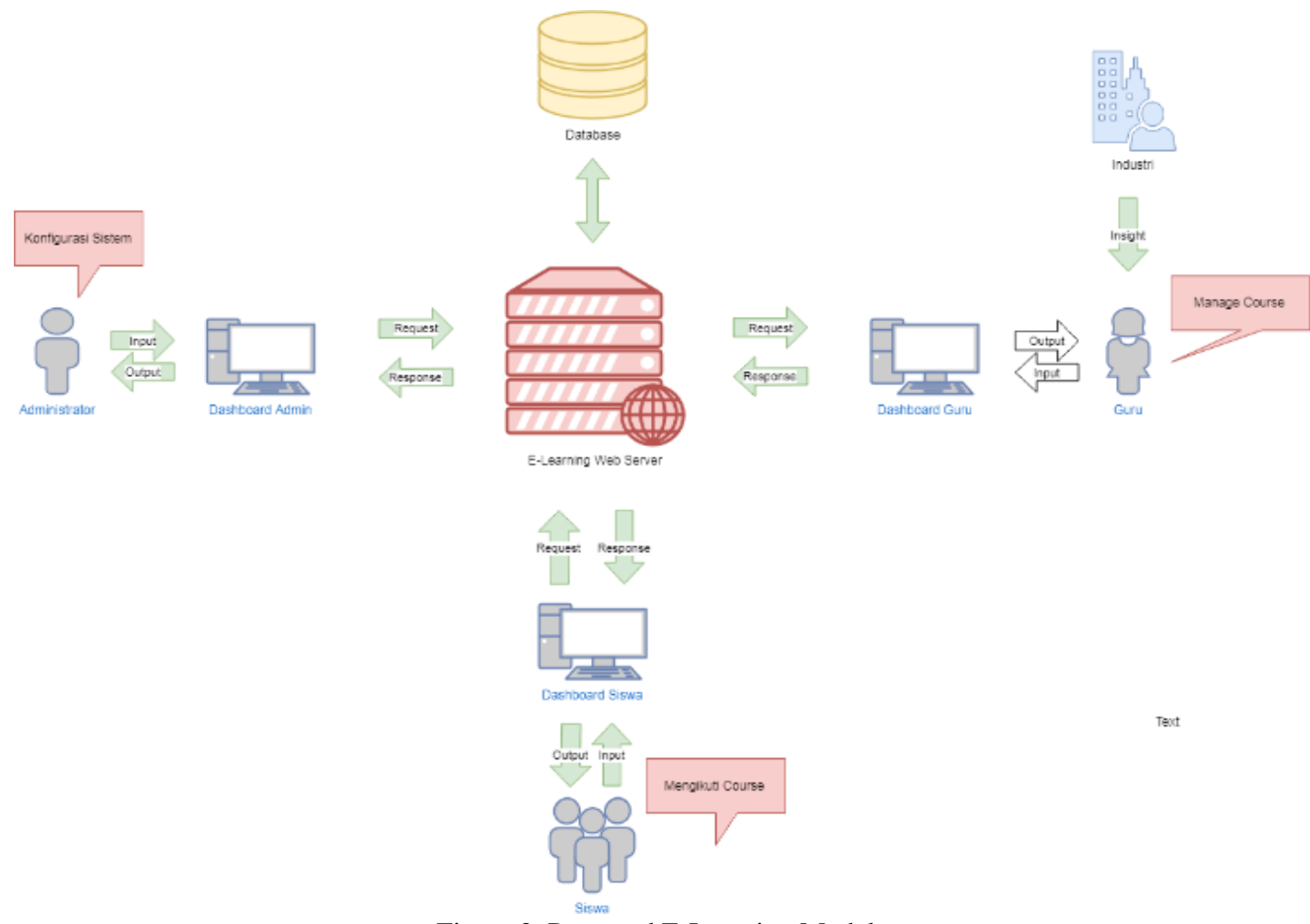

Figure 2. Proposed E-Learning Model

\begin{tabular}{|c|c|}
\hline ID & Requirement \\
\hline FR05 & $\begin{array}{l}\text { A system should facilitate administrator to } \\
\text { create courses that related to categories that } \\
\text { created before. }\end{array}$ \\
\hline \multirow{7}{*}{ FR06 } & $\begin{array}{l}\text { A system should facilitate teacher to manage } \\
\text { their courses, including: }\end{array}$ \\
\hline & - Complete the description on the course \\
\hline & - $\quad$ Add material to the courses \\
\hline & - $\quad$ Manage tasks \\
\hline & - Manage quizzes \\
\hline & $\begin{array}{l}\text { - Manage discussion forums in each } \\
\text { course }\end{array}$ \\
\hline & - $\quad$ Manage student grades for each course \\
\hline FR07 & $\begin{array}{l}\text { A system should facilitate student to view } \\
\text { materials of their courses }\end{array}$ \\
\hline FR08 & $\begin{array}{l}\text { A system should facilitate student to join } \\
\text { forum discussion of their courses }\end{array}$ \\
\hline FR09 & $\begin{array}{l}\text { A system should facilitate student to do the } \\
\text { task of their courses }\end{array}$ \\
\hline FR10 & $\begin{array}{l}\text { A system should facilitate student to do a quiz } \\
\text { of their courses }\end{array}$ \\
\hline FR11 & $\begin{array}{l}\text { A system should facilitate student to grade of } \\
\text { their courses }\end{array}$ \\
\hline
\end{tabular}

\section{B. PROPOSED E-LEARNING MODEL}

Based on functional requirement above, this study proposed e-learning model as follow: 
Figure 2 explains how each element (Actor and System) in the use of the e-learning system interacts and doing each roles. The following is a detailed explanation of each role in system utilization:

Table 2. Roles in Proposed E-Learning Model

\begin{tabular}{|c|c|c|c|}
\hline No & & Element & Description \\
\hline \multirow[t]{3}{*}{1} & User & Administrator & $\begin{array}{l}\text { The administrator has } \\
\text { task for configuring } \\
\text { system from user } \\
\text { management to the } \\
\text { courses. }\end{array}$ \\
\hline & & Teacher & $\begin{array}{l}\text { The teacher is the main } \\
\text { facilitator in the } \\
\text { teaching and learning } \\
\text { process which is in } \\
\text { charge of the } \\
\text { management of their } \\
\text { courses, the assignment } \\
\text { up to the assessment. In } \\
\text { carrying out its role, the } \\
\text { teacher must actively } \\
\text { assess the needs of the } \\
\text { industries so that they } \\
\text { can get insight to create } \\
\text { materials in the } \\
\text { teaching and learning } \\
\text { process using the e- } \\
\text { learning system. }\end{array}$ \\
\hline & & Student & $\begin{array}{l}\text { Students as the main } \\
\text { actors who will follow } \\
\text { each course that given } \\
\text { to them. }\end{array}$ \\
\hline
\end{tabular}

\begin{tabular}{|c|c|c|}
\hline No & Element & Description \\
\hline 2 & Dashboard & $\begin{array}{l}\text { Each user will have access } \\
\text { into dashboard page } \\
\text { according to the user } \\
\text { category. Each user will have } \\
\text { a different dashboard } \\
\text { according to the access rights } \\
\text { of each user category. }\end{array}$ \\
\hline 3 & $\begin{array}{l}\text { E-learning Web } \\
\text { Server }\end{array}$ & $\begin{array}{l}\text { Web server for running e- } \\
\text { learning application }\end{array}$ \\
\hline 4 & Database & $\begin{array}{l}\text { Database management } \\
\text { system. }\end{array}$ \\
\hline 5 & Industries & $\begin{array}{l}\text { Industries in this model is an } \\
\text { external entity that cannot be } \\
\text { separated. In practice, } \\
\text { industrial needs will be an } \\
\text { insight for teachers in } \\
\text { carrying out the teaching and } \\
\text { learning process especially } \\
\text { using the developed e- } \\
\text { learning system. }\end{array}$ \\
\hline
\end{tabular}

\section{SYSTEM DESIGN}

Based on results of the requirements analysis and the proposed model in this study, next phases are design and implementation of the system that suit to the requirements and models proposed.

This stage contains system design and implementation which refers to the functional requirements and proposed e-learning model. System design at this stage is use case diagram that explains the actors interactions with system functionality. Here is the design of use case diagrams for e-learning applications that are built:

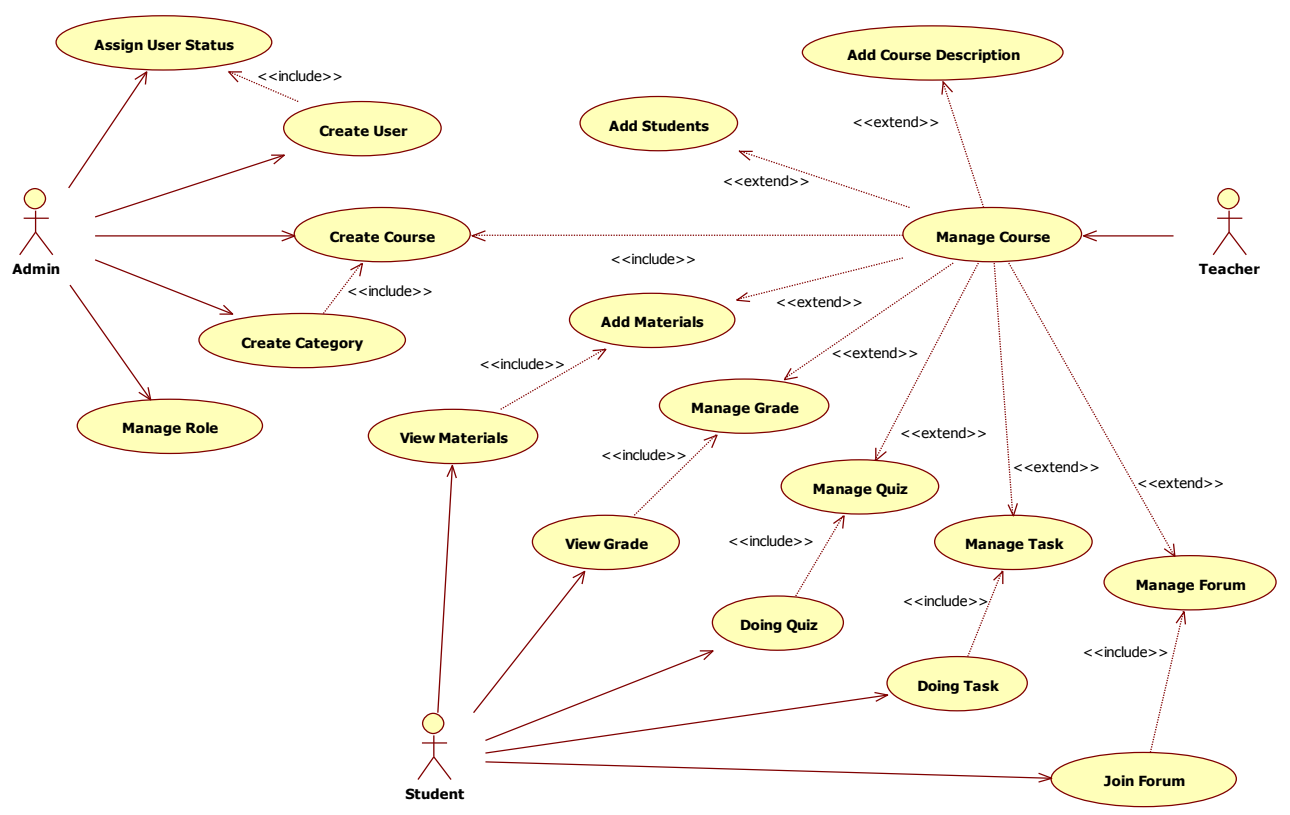

Figure 3. Use Case Diagram 
The following are the actors involved in the use case diagram above:

Table 3. Actor Description

\begin{tabular}{|c|c|c|}
\hline No & Aktor & Deskripsi \\
\hline 1 & Admin & $\begin{array}{l}\text { Actors with this role have the } \\
\text { authority to manage e-learning } \\
\text { systems in general and ensure that } \\
\text { all the needs of other actors } \\
\text { related to this system can be } \\
\text { fulfilled }\end{array}$ \\
\hline 2 & Teacher & $\begin{array}{l}\text { Actors with this role are tasked to } \\
\text { carry out the learning process } \\
\text { using an e-learning system. In this } \\
\text { system, the actor with this role is } \\
\text { in charge of managing their } \\
\text { courses }\end{array}$ \\
\hline 3 & Student & $\begin{array}{l}\text { The actor with this role has task } \\
\text { to follow each course in the e- } \\
\text { learning system where the actor } \\
\text { joins. }\end{array}$ \\
\hline
\end{tabular}

Here is a list of use cases with a brief description of the use case in the use case diagram above.

\begin{tabular}{|c|c|c|}
\hline No & Use Case & Description \\
\hline 1 & Manage Role & $\begin{array}{l}\text { The system displays a list of } \\
\text { roles in the e-learning system } \\
\text { so that authorized users can } \\
\text { manage each role in this } \\
\text { system. }\end{array}$ \\
\hline 2 & Create User & $\begin{array}{l}\text { The system provides a form } \\
\text { for adding users }\end{array}$ \\
\hline 3 & $\begin{array}{l}\text { Assign User } \\
\text { Status }\end{array}$ & $\begin{array}{l}\text { The system provides } \\
\text { facilities for giving status to } \\
\text { users }\end{array}$ \\
\hline 4 & Create Category & $\begin{array}{l}\text { The system provides an } \\
\text { additional category form }\end{array}$ \\
\hline 5 & Manage Course & $\begin{array}{l}\text { The system displays a list of } \\
\text { courses in the e-learning } \\
\text { system so that authorized } \\
\text { users can manage each } \\
\text { course on this system. }\end{array}$ \\
\hline 6 & $\begin{array}{l}\text { Add Course } \\
\text { Description }\end{array}$ & $\begin{array}{l}\text { The system provides a form } \\
\text { for adding descriptions to } \\
\text { each course. }\end{array}$ \\
\hline 7 & Add Materials & $\begin{array}{l}\text { The system provides a form } \\
\text { of adding material to each } \\
\text { course }\end{array}$ \\
\hline 8 & Add Student & $\begin{array}{l}\text { The system provides a form } \\
\text { of adding users to each } \\
\text { course }\end{array}$ \\
\hline 9 & Manage Quiz & $\begin{array}{l}\text { The system displays a list of } \\
\text { quizzes on each course so } \\
\text { that authorized users can } \\
\text { manage each quiz on this } \\
\text { system. }\end{array}$ \\
\hline
\end{tabular}

\begin{tabular}{lll}
\hline No & \multicolumn{1}{c}{ Use Case } & \multicolumn{1}{c}{ Description } \\
\hline 10 & Manage Task & $\begin{array}{l}\text { The system displays a list of } \\
\text { tasks on each course so that } \\
\text { authorized users can manage } \\
\text { each task on this system. }\end{array}$ \\
\hline 11 & Manage Forum & $\begin{array}{l}\text { The system facilitates } \\
\text { discussion forums on each } \\
\text { course }\end{array}$ \\
\hline 12 & Manage Grade & $\begin{array}{l}\text { The system displays a list of } \\
\text { values on each course so that } \\
\text { authorized users can manage } \\
\text { each value on this system. }\end{array}$ \\
\hline 13 & Join Forum & $\begin{array}{l}\text { The system facilitates users } \\
\text { to join forums discussion }\end{array}$ \\
\hline 14 & View Materials & $\begin{array}{l}\text { The system displays a list of } \\
\text { materials from the course } \\
\text { followed by the user. }\end{array}$ \\
\hline 15 & Doing Task & $\begin{array}{l}\text { The system provides a form } \\
\text { to do the task }\end{array}$ \\
\hline 16 & Doing Quiz & $\begin{array}{l}\text { The system provides a form } \\
\text { to work on quizzes }\end{array}$ \\
\hline 17 & View Grade & $\begin{array}{l}\text { The system displays the } \\
\text { grade on the course followed } \\
\text { by the user }\end{array}$ \\
& &
\end{tabular}

D. SYSTEM IMPLEMENTATION

Below is the implementation of the system that has been carried out at the design stage:
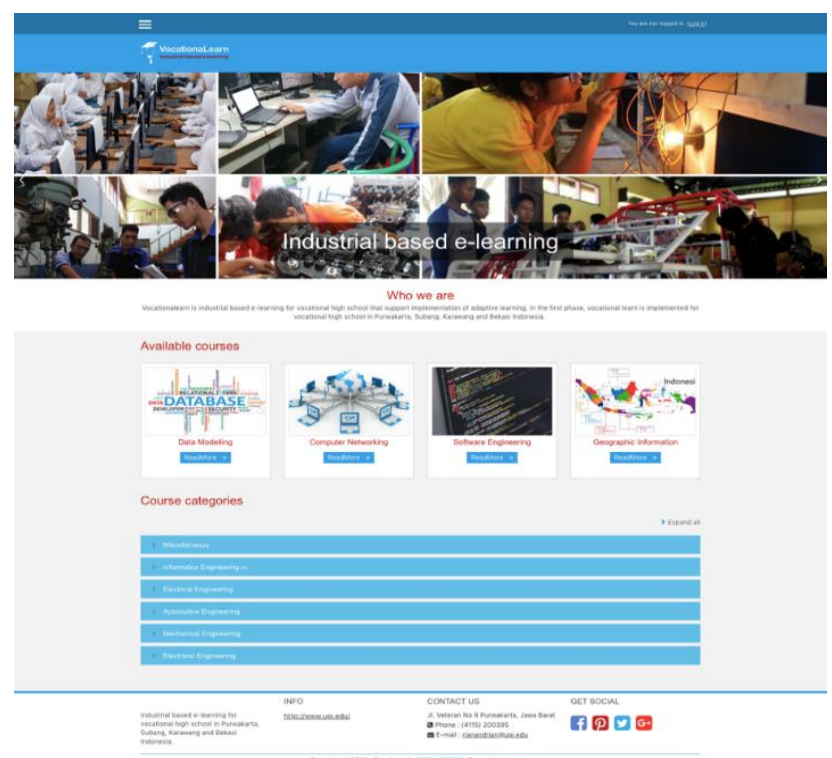

Figure 4. Main E-Learning Page 


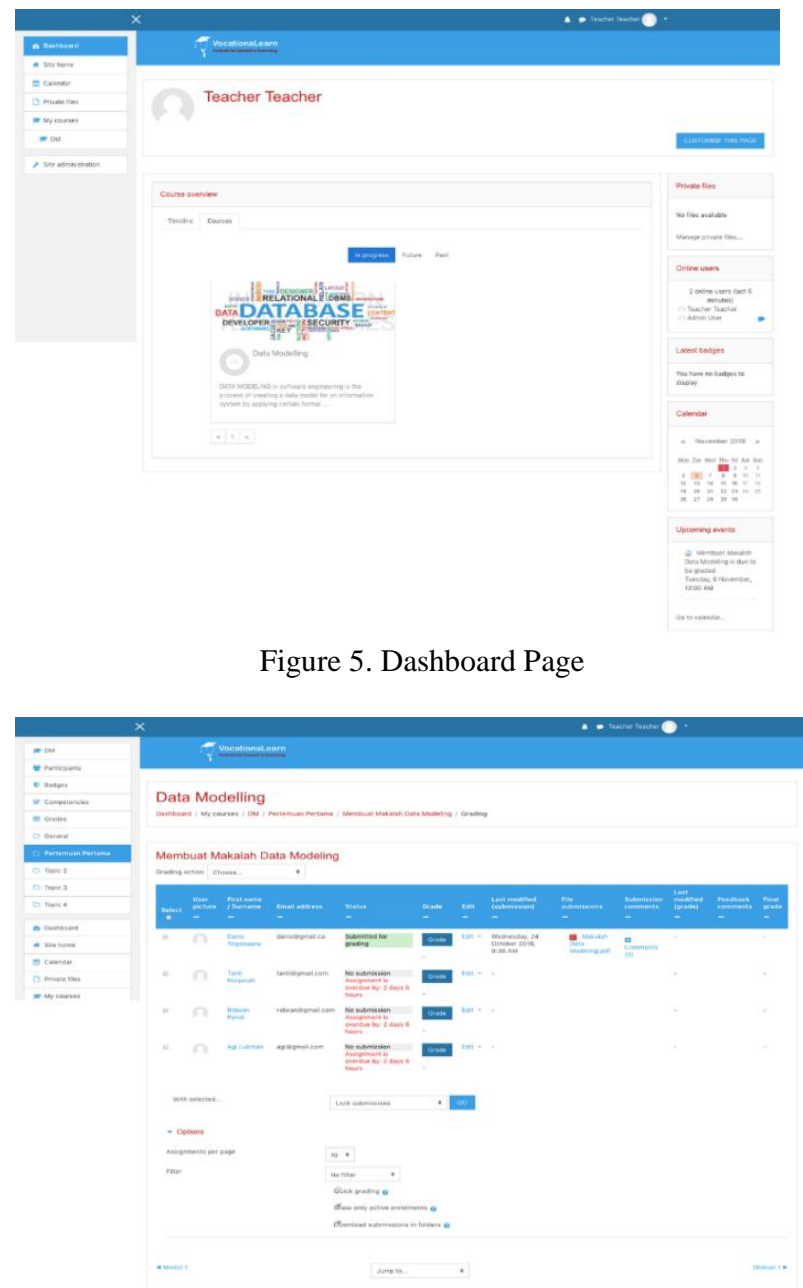

Figure 6. Grade List Page

The developed e-learning system has the following features:

Administrator Features

Table 5. Administrator Features

\begin{tabular}{|c|c|c|}
\hline No & Feature & Description \\
\hline 1 & $\begin{array}{l}\text { Manage } \\
\text { Role }\end{array}$ & $\begin{array}{l}\text { Feature used by } \\
\text { Administrators to define } \\
\text { roles from each user }\end{array}$ \\
\hline 2 & $\begin{array}{l}\text { Create } \\
\text { User }\end{array}$ & $\begin{array}{l}\text { Feature used by } \\
\text { Administrators to add } \\
\text { new users } \\
\text { (Administrators, } \\
\text { Teachers, Students) }\end{array}$ \\
\hline 3 & $\begin{array}{l}\text { Assign } \\
\text { User Status }\end{array}$ & $\begin{array}{l}\text { Feature used by } \\
\text { Administrators to provide } \\
\text { status to other users }\end{array}$ \\
\hline 4 & $\begin{array}{l}\text { Create } \\
\text { Category }\end{array}$ & $\begin{array}{l}\text { Features used by } \\
\text { Administrators to manage } \\
\text { learning categories }\end{array}$ \\
\hline 5 & $\begin{array}{l}\text { Manage } \\
\text { Course }\end{array}$ & $\begin{array}{l}\text { Feature used by } \\
\text { Administrators to manage } \\
\text { courses in general }\end{array}$ \\
\hline
\end{tabular}

Teacher Features

Table 6. Teacher Features

\begin{tabular}{|c|c|c|}
\hline No & Feature & Description \\
\hline 1 & $\begin{array}{l}\text { Add } \\
\text { Course } \\
\text { Description }\end{array}$ & $\begin{array}{l}\text { Features used by the } \\
\text { teacher to complete the } \\
\text { description of each course } \\
\text { taught }\end{array}$ \\
\hline 2 & $\begin{array}{l}\text { Add } \\
\text { Materials }\end{array}$ & $\begin{array}{l}\text { Features used by the } \\
\text { teacher to complete the } \\
\text { material in each course }\end{array}$ \\
\hline 3 & $\begin{array}{l}\text { Add } \\
\text { Student }\end{array}$ & $\begin{array}{l}\text { Feature used by the } \\
\text { teacher to add students to } \\
\text { the course they are } \\
\text { teaching }\end{array}$ \\
\hline 4 & $\begin{array}{l}\text { Manage } \\
\text { Quiz }\end{array}$ & $\begin{array}{l}\text { Features used by the } \\
\text { teacher to manage quizzes } \\
\text { that given to students }\end{array}$ \\
\hline 5 & $\begin{array}{l}\text { Manage } \\
\text { Task }\end{array}$ & $\begin{array}{l}\text { Features that are used by } \\
\text { the teacher to manage } \\
\text { tasks that given to } \\
\text { students }\end{array}$ \\
\hline 6 & $\begin{array}{l}\text { Manage } \\
\text { Forum }\end{array}$ & $\begin{array}{l}\text { The feature used by the } \\
\text { Teacher to manage } \\
\text { forums discussion }\end{array}$ \\
\hline 7 & $\begin{array}{l}\text { Manage } \\
\text { Grade }\end{array}$ & $\begin{array}{l}\text { Features used by the } \\
\text { teacher to manage the } \\
\text { values obtained by } \\
\text { students }\end{array}$ \\
\hline
\end{tabular}

- $\quad$ Student Features

Table 7. Student Features

\section{No Feature Description}

\begin{tabular}{lll}
\hline 1 & $\begin{array}{l}\text { Join } \\
\text { Forum }\end{array}$ & $\begin{array}{l}\text { Features used by students } \\
\text { to join the forum } \\
\text { discussion }\end{array}$ \\
\hline 2 & $\begin{array}{l}\text { View } \\
\text { Materials }\end{array}$ & $\begin{array}{l}\text { Features that are used by } \\
\text { students to view material } \\
\text { from the course they are } \\
\text { taking }\end{array}$ \\
\hline 3 & $\begin{array}{l}\text { Doing } \\
\text { Task }\end{array}$ & $\begin{array}{l}\text { Features used by students } \\
\text { to do assignments given } \\
\text { by the teacher }\end{array}$ \\
\hline 4 & $\begin{array}{l}\text { Doing } \\
\text { Quiz }\end{array}$ & $\begin{array}{l}\text { Features used by students } \\
\text { to do quizzes given by the } \\
\text { teacher }\end{array}$ \\
\hline 5 & $\begin{array}{l}\text { View } \\
\text { Grade }\end{array}$ & $\begin{array}{l}\text { Features used by students } \\
\text { to see the obtained grade }\end{array}$ \\
\hline & &
\end{tabular}




\section{E. SYSTEM TESTING}

System testing is conducted to ensure system functionality according to user needs, so that the system can fulfill one of aspect quality of the system, namely functionality. A quality system will increase its utilization by users[11]. System testing that conducted in this study is black box testing.

All features for Administrators, Teachers and Students from the system developed have successfully passed the functional testing stage. Based on the testing results that has been conducted, it can be concluded that the system developed is ready to be used.

\section{IV.CONCLUSION}

Vocational High Schools (SMK) have an important role in improving the quality of human resources to meet industrial needs. However, the current education system in Vocational Schools still cannot compete compared to other countries, especially in Purwakarta, Subang, Karawang, Bekasi (PURWASUKASI).

This study was conducted to improve the quality of education in Vocational Schools with a case study in PURWASUKASI to help prepare qualified human resources in accordance with industry needs. In this study, an e-learning system has been developed and tested from the functional aspects of the system. Based on the results of functional tests that have been conducted, it can be concluded that the system developed is ready for use.

There are several suggestions related to further research, including:

1. Based on the research that has been done, it is recommended that the e-learning system model that has been created be validated by implementing in vocational high school in accordance with case studies to support adaptive learning.

2. Conducted evaluation of the model and e-learning system that has been developed is in accordance with the needs so we can get insigh about the model and features for further development.

3. Conducted further development of the model and e-learning system that has been developed, based on insigh from the results of the assessment that conducted in point two.

\section{REFERENCES}

[1] P. A. Julianto, "Melibatkan Peran SMK untuk Mendorong Daya Saing Industri - Kompas.com.” [Online]. Available:

https://ekonomi.kompas.com/read/2017/02/10/08 0000726/melibatkan.peran.smk.untuk.mendorong .daya.saing.industri. [Accessed: 29-Jan-2019].

[2] B. P. Statistik, "Survey Jumlah Pengguna Internet," 2013. .

[3] P. Pemerintah, "Peraturan Pemerintah Republik Indonesia Nomor 17 Tentang Pengelolaan dan Penyelenggaraan Pendidikan." 2010.
[4] H. Budiman, "Peran Teknologi Informasi Dan Komunikasi Dalam Pendidikan," J. Pendidik. Islam Al-Tadzkiyyah, vol. 8, no. I, pp. 75-83, 2017.

[5] K. Grenman, M. Isomursu, M. Federley, and A. Seisto, "Benefits and Financial Impacts of Adopting Technology in Learning," in International Conference Mobile Learning 2013, 2013, pp. 177-182.

[6] M. Masrom, "The Technology Acceptance Model and The E-learning."

[7] H. D. Surjono, Membangun Course E - Learning Berbasis Moodle. Yogyakarta: UNY Press, 2013.

[8] P. Brusilovsky and C. Peylo, "Adaptive and Intelligent Web-based Educational Systems," Peylo, 2003.

[9] "Moodle." [Online]. Available: https://moodle.org/.

[10] S. Dwivedi, "IJARCCE Software Development Life Cycle Models-A Comparative analysis," Int. J. Adv. Res. Comput. Commun. Eng., vol. 5, no. 2, 2016.

[11] R. Andrian, B. Hendradjaya, and W. D. Sunindyo, "Software assessment model using metrics products for e-Government in the G2B model," in 2016 4th International Conference on Information and Communication Technology (ICoICT), 2016, pp. 1-6. 